Canadian Studies in Population, Vol. 31(2), 2004, pp. 237-260

\title{
Age-Specific Household Size as a Demographic Aspect of Regional Disparity: Czech Republic, 1991
}

\author{
Abraham Akkerman \\ Department of Geography \\ University of Saskatchewan \\ Saskatoon, Saskatchewan, Canada
}

\begin{abstract}
The post-communist transition to market economy in Central Europe over the last decade of the twentieth century had a significant impact on the demographic profile of the former Soviet bloc countries. Largely due to government policy and market conditions related to housing, this observation is particularly true for the Czech Republic. The present study shows housing as a facet of regional demographic differences within the Czech Republic. The household composition matrix is applied here as a demographic gauge to the behavioral response of households to Czech housing markets and policy. The matrix provides here a glance at households' demographic behavior in the capital city of Prague and in the country's other regions, during the early transition period, based on observations from the 1991 census. A summary feature of household composition is the age-specific household size shown for the various regions of the Czech Republic to trace the reduced standard Gamma function. Anomalies detected in the trajectory of age-specific household size for Prague confirm the unique housing market conditions in the capital city, and point to a commensurate demographic response in Prague as opposed to the rest of the country.
\end{abstract}

Keywords: Czech Republic, household composition, regional disparity, agespecific household size 
Abraham Akkerman

\section{Résumé}

The post-communist transition to market economy in Central Europe over the last decade of the twentieth century had a significant impact on the demographic profile of the former Soviet bloc countries. Largely due to government policy and market conditions related to housing, this observation is particularly true for the Czech Republic. The present study shows housing as a facet of regional demographic differences within the Czech Republic. The household composition matrix is applied here as a demographic gauge to the behavioral response of households to Czech housing markets and policy. The matrix provides here a glance at households' demographic behavior in the capital city of Prague and in the country's other regions, during the early transition period, based on observations from the 1991 census. A summary feature of household composition is the age-specific household size shown for the various regions of the Czech Republic to trace the reduced standard Gamma function. Anomalies detected in the trajectory of age-specific household size for Prague confirm the unique housing market conditions in the capital city, and point to a commensurate demographic response in Prague as opposed to the rest of the country.

Mots-clés: Czech Republic, household composition, regional disparity, agespecific household size

\section{Introduction}

The recent expansion of the European Union has evoked considerable debate as to the management of economic, social and cultural equity issues within each of the EU accession countries in the former Soviet bloc of Central and Eastern Europe (Kancs, 2001). Among the East- and Central-European accession countries, the Czech Republic has been considered one of the strongest. Regional disparity within the Czech Republic, therefore, is an issue that far exceeds its own geographical confines. Historically, regional disparity within the geographical area referred to today as the Czech Republic has been overshadowed by the much more evident inequity between Slovakia and the Czech lands within the former Czechoslovakia. Inequity has been seen as a major sticking point between the two geopolitical partners within Czechoslovakia, and a formative issue in the emergence of the Czech Republic and Slovakia as independent states in 1993. The struggle for resources and development between the Czech lands and Slovakia in the period 1918 - 1992, had occurred within the democratic Czechoslovak Republic (1918-1938, 19451948), then within the communist state labeled initially, from 1948 till 1961, as 
Age-Specific Household Size as a Demographic Aspect of Regional Disparity: Czech Republic, 1991

the Czechoslovak Republic, and then, as the Czechoslovak Socialist Republic. ${ }^{1}$ The struggle between the two parts of Czechoslovakia was heightened following the Velvet Revolution of 1989 that put an end to the communist regime. The 'Velvet Divorce' that took effect on January 1, 1993, sanctioned the ultimate break-up of Czechoslovakia into the independent Czech Republic and Slovakia.

\section{Czech Regional Disparity Before, During and After the Collapse of Communism}

Within the Czechoslovak state, regional disparity was justifiably considered as emanating from the significant cultural, economic and demographic differences between the lesser-developed Slovakia in the east, and the Czech lands in the western part of the country. Due to the sharp differences in education, demography and industrial output, between the Czech and the Slovak components, major efforts of Czechoslovak governments have centered on the industrialization of Slovakia. The communist government of Czechoslovakia between the years 1948 and 1989 had seen to it that accelerated attempts for industrial parity of Slovakia would become the main focus of regional policy, as well as its propaganda stratagem. Resources were poured into Slovakia where megaprojects such as the East Slovak Ironworks in the 1960s (Brzica, 2001) or the Gab_íkovo Water Project of the 1970s (Balon and Hol_ík, 1999) were launched by the socialist government at great expense and often without much foresight.

The major development projects within Slovakia, not the least due to their significant propaganda value, had a considerable impact upon the notion of Czechoslovak equity and unity (Pavlínek, 1992). Postcommunist analysis had shown, however, that the socialist equalization bids had been counter-productive to the economic growth of Czechoslovakia (D_dek, 1996: 23-26). Considered one of the most industrialized nations between World Wars I and II, Czechoslovakia after the communist putsch of 1948, had gradually descended to the rank of a colonial serf of the former Soviet Union. On the eve of the collapse of communism in Central and Eastern Europe in 1989, the country still ranked among the leading nations of the Communist bloc, but its industrial output was no match to countries with which Czechoslovakia had successfully competed only half a century earlier (Pr_cha, 1997).

After the Velvet Revolution of 1989 policy towards economic equity between Czech and Slovak regions became a secondary issue. In fact, as Pavlínek (1995) had argued, the economic transformation in Czechoslovakia after the collapse of state socialism in 1989 had resulted in the re-emergence of uneven development, generally favoring the Czech lands, which contributed to the disintegration of 
Czechoslovakia on December 31, 1992. Under such circumstances, the question of disparity between urban and rural regions within both component territories, or regional disparity within the Czech lands, was seen as secondary or tertiary (Hraba et al., 1999). Accordingly also, past attempts at equalization of Slovakia during the communist regime have begun to be viewed as responsible for latter day economic difficulties of the Czech Republic as well as for aspects of regional disparity within it (Synek and Kubálek, 1993).

The integration of the Czech Republic in the EU highlights the problem of inequity within the country, and begs the question of inequity measures. The impact upon the socio-economic conditions throughout the Czech Republic has been visible in the decline of natural population growth in Prague, in tandem with skyrocketing real-estate prices in the Czech capital, as opposed to slow increase in wages and real-estate prices, but faster natural population growth outside the national capital (Eskinasi, 1995). As Lux (2000) has pointed out, housing has been one of the most significant links between Czech economy and demography, attaining particular significance in the process leading to the Czech accession to the EU. Observation and prognostication of socio-economic and demographic changes has led, accordingly, to considerable debate converging on the significance of housing as a gauge of Czech social and economic conditions (Lux and Sunega, 2003). as well as a measure of Czech regional demographic differentials (Musil, 1995). The difficulty in choosing any one traditional housing gauge for this purpose has been highlighted, for example, by He_manová and Kosteleck_(2000) who had acknowledged that no clear causes for Czech regional differences in common housing indicators could be discerned.

In 1992 Pavlínek had suggested that in order to address the asymmetry in development within lands comprising the former Czechoslovakia, quality of the environment and infrastructure, as well as regional planning and policy decentralization, should be adopted. Later, Uhlí_(1998) had argued that regional change in the Czech Republic is reflected in the restructuring of social capital networks and in the redefinition of symbolic capital of foreign investment. This has been somewhat in contrast with more traditional calls, originating from both economic and sociological quarters of the country's academic establishment, for analytic gauges rather than policy statements (e.g., Machonin, 1994). Zaniewski (1992), in particular, had pointed out that East European regional inequalities are reflected in different rates of population growth, in uneven ethnic patterns and in varying degrees of subordination of social behavior to government policy. 
Age-Specific Household Size as a Demographic Aspect

of Regional Disparity: Czech Republic, 1991

\section{Household Size and Housing as Measures of Disparity in the Czech Republic}

It is within the recognition for the need of analytic measures in the observation of Czech regional differences that the Czech census of 1991 has emerged as a particularly important tool. The census provides an unusual statistical glimpse at the transition period between the fall of the Czechoslovak communist regime in 1989, and the disintegration of Czechoslovakia three years later. As such the census of 1991 has often been used as a tool showing the asymmetry in development between the Czech and the Slovak components of Czechoslovakia (Machonin, 1994; Garner and Terrell, 1998). Less frequent has been the use of the 1991 census in the analysis of disparity within the eight regions comprising the Czech Republic. Although several socio-economic and demographic indicators showing varying levels in Czech regional disparity have been employed since the publication of the 1991 census in 1995, no single gauge has emerged as comprehensively applicable.

Elsewhere, early studies as well as more contemporary research have often viewed migration as such a gauge. Regional development had been viewed as a cause of migration (Harris and Todaro, 1970) or, alternatively, interregional migration has been regarded as a measure of regional disparity (e.g., Dustmann, 2003). But in spite of such a use of migration elsewhere, in most Czech studies this has not been the case. As Fidrmuc (2000) has shown interregional migration in the Czech Republic following the Velvet Revolution has dropped, even though there has been a widening gap in average wages, for example, between Prague and the rest of the country (Eskinasi, 1995). Migration, in fact, has been recognized as an insufficient explanation of the asymmetry in Czech regional development (Fidrmuc, 2000).

Behind much of the low interregional migration figures is likely the prohibitive cost of housing in Prague, combined with relatively low wages across much of the country. Housing and wages have been often used in the measurement of disparity elsewhere (e.g., Drudy and Punch, 2002), and with a limited success within the context of the 1991 Czech census as well (Garner and Terrell, 1998). While differences in housing and wages between the Czech lands and Slovakia have been always pronounced, such differences between the Czech regions have been subtle, and more difficult to detect. Thus, since the early years following the 'Velvet Divorce,' Czech regions with lower housing costs have been consistently experiencing also lower wages (e.g., Telgarsky et al., 1993), and accordingly Czech housing and wage differentials have had a disappointing 
Abraham Akkerman

performance as socio-economic gauges (Illner, 1998). After reviewing Czech accession credentials, Marek and Baun (2002), for example, had concluded that neither housing nor wages have been adequate in measuring the EU's impact on Czech structural aid programs. The problem of differential housing costs has also been reported to encounter similar difficulties elsewhere (Giannias, 1998).

Nevertheless, the gauging of wellbeing throughout the Czech Republic by Illner (1998) has pointed out variations through such measures as vacancy rates and cost of housing. The modicum of success in the use of housing indicators for the measurement of interregional differences points to yet another option. Past micro-economic studies have shown increasingly that demographic gauges relating to the household, and to average household size in particular, may be seen as reflecting social and even cultural standards. Prevailing living arrangements within a population, economic conditions, and certainly housing costs and income, have been traced with varying levels of success to the household (e.g., Awan et al., 1992). Czech economists and sociologists have seconded such an approach on occasion, utilizing average household size as a gauge (Vav_ejnová and Morav_íková, 1995).

Average household size, or the average number of persons per household, as the ratio of persons in households to the number of households (Burch, 1970), has been only seldom applied to multitudes of geographical areas (for a notable exception, see Moring, 2003). Furthermore, as a socio-economic measure average household size has had an undistinguished record, the lack of interest in it perhaps the result of studies such as Ebert's (1995) which had shown that there is no relationship between household size and income. Interregional comparisons of household size, accordingly, have been scarce (Hardman and Ioannides, 2004).

\section{Household Composition: Prague and the Rest of the Czech Republic}

The notion of average household size alludes to a crude measure, and studies in regional analysis that have employed average household size as a socioeconomic gauge, have interpreted it precisely in this sense (Mapalad-Ruane and Rodriguez, 2003). As a demographic measure the concept of household size carries, however, ramifications for considerable efficacy, particularly within the context of interregional analysis.

It is a matter of intuitive appeal to consider changes in the size of the average household throughout its life-course. It could be argued that as a singular population unit the household comes into being with the identification of one 
Age-Specific Household Size as a Demographic Aspect of Regional Disparity: Czech Republic, 1991

person as the household's head, and this singular population unit ceases to exist as the same household with the departure of its household-head (Akkerman, 1994). The change in household size between the household's commencement and its demise, is determined by recruitment and departure of individuals into or from the household. Accordingly, a longitudinal measurement over time of average household size could be endeavored against the aging of the average household's head. A longitudinal follow-up of households, however, is usually impossible over an extended period of time, and the monitoring of changing size of same households against the age of their heads is not an operationally valid undertaking.

Available usually are panel data from surveys or censuses. In a contrivance similar to the concept of the period-life table in demography, longitudinal change in household size can be re-enacted from such panel data. From the panel data the size of households is specified according to the age of their corresponding heads, and thus average household size specific to age-groups of household heads can be derived as well. The re-enacted change in average household size according to the age of household head can be considered a substitute for a longitudinal follow-up over time. Average household size thus no longer performs as a crude ratio between the number of persons and the number of households at a single point in time, but as an age-specific measure geared to the age of the household head (householder in the following).

The census depiction of households from which the age-specific household size arises is the matrix notion of household composition. The household composition matrix is a crosstabulation of individuals and their corresponding householders, usually by categories of age (Akkerman, 1996). Through the crosstabulation each individual is assumed to be a member of a household, and demographic traits are expressed jointly for individuals and for households. This approach enables to integrate substantive considerations, such as children present or household size, within a single, tabular expression. Households are considered population-units, and demographic change occurring within households is perceived as manifested in the redistribution of population and households over time. Within the scope of re-enactment of such redistribution over time, household composition at the smaller, regional or urban, levels proves particularly instrumental.

The household composition table (Rychta íková and Akkerman, 2003) shows average number of persons throughout the entire range of ages, $0+$, per household whose householder is identified by an age within the range 15+. Tables 1 and 2, as examples of age-specific household composition, display arithmetic ratios held in 1991 between household-persons and householders throughout various age groups, in Prague and in the rest of the Czech Republic, 
respectively. In the present case the age-groups are in standard 5-year intervals, commencing at 0-4 (age group 1) for all persons within households, and at 15-19 (age group 4) for the subset of householders. Thus, persons' age groups listed as headings for rows $i(i=1,2,3,4, \ldots)$ correspond to age-intervals $0-4,5-9,10$ $14,15-19, \ldots$, while householder age groups listed for headings of columns $j(j=$ $1,2,3,4 \ldots)$ correspond to age-intervals $15-19,20-24,25-29,30-34, \ldots$ A brief reflection shows that the sum of entries in each column $j$ of the household composition table yields the average household size for householders in householder age groups $j(j=1, \ldots, 16)$.

The age-specific household size in the household composition table emerges now as a cross-sectional measure of household lifecourse. Such interpretation applies also to any age-range within the household composition. In the household composition table a diagonal follow-up of entries re-enacts the net result over time of household formation, attrition, survival and recruitment of persons in households. In the following, the relative differences in corresponding values of the upper right corners in Tables 1 and 2 will be shown as critical to the interpretation of disparity between Prague and the rest of the country.

\section{Trajectories of Age-Specific Household Size: Prague and Rest of the Country}

In the household composition table, exemplified in Tables 1 and 2, aging and progressive household affiliation of the theoretical average household person are shown along the diagonals. Due to recruitment and departure of persons into and from households, persons' household-affiliation changes, and thus the values of the household composition table are only net-results of overall household dynamics in the population. By this reasoning, average number of persons per household along the horizontal dimension of householder age groups in each of Tables 1 and 2, is interpreted as a function of householder's age. Age-specific household size emerges thus as an indicator of household life course, measured against the age of householders. Table 3 shows the agespecific household size in 1991 for all eight regions of the Czech Republic.

Based upon these considerations household composition extends beyond its description as a relational demographic structure at a single point in time. Viewed somewhat analogously to the period life-table in demography, the household composition table, in fact, is a net-indicator of household formation, change and attrition over time. The period life-table and the household composition table inform existing demographic structures at a single period and at a single point in time, respectively: The life-table references the survival 
Age-Specific Household Size as a Demographic Aspect of Regional Disparity: Czech Republic, 1991

pattern of age groups observed during a single period of time; the householdcomposition table describes the intra-household age distribution of householdpersons within the average household, observed at a single point in time. But just as the life-table shows a theoretical (stationary) population during the entire life course of a cohort, so too the household composition table (Tables 1 and 2) displays, over the entire theoretical life course of the average household, the net result of aging, reproduction, as well as household formation and attrition.

Even though not every household comprises a family, household formation as well as household size in most human populations might be considered related to both marriage and fertility. Based on the 1991 census of the Czech Republic a recent demographic study has shown, indeed, a correspondence between Czech regional fertility patterns and household composition (Rychta_íková and Akkerman, 2003). On the other hand also, Frejka (1980) had pointed out correspondence between pro-natalist policies, including mortgages to newlyweds, and family patterns in Czechoslovakia during the 1970s. In the case of the eight Czech regions, the question of policy and family- or householdcomposition, thus, attains additional significance.

The trajectory of age-specific fertility in a population and the trajectory of agespecific rates of first marriage usually trace the same or similar trajectories (e.g., Pressat, 1978: 74-79, 92-97). One of the more common approximations for trajectories of age-specific rates of both first marriage and fertility has been the Gamma probability density function (Coale and McNeil, 1972; Hoem et al., 1981; cf. also Frejka and Calot, 2001). The Gamma function, shown by a curve in Figure 1, has its scale parameter selected as 1, and its shape parameter selected as $=5$, in correspondence to the length of age intervals. The curve has a coefficient of 1.51, corresponding to the average household size of the first age group of householders, and an intercept of 10. Since the scale parameter is 1, the Gamma function in Figure 1 is shortened to the reduced standard Gamma probability density function,

$$
\text { (1) } \quad f(x)=1.51+10 * \mathrm{x}^{\alpha-1} e^{-\mathrm{x}} / \Gamma(\alpha) \text {, }
$$

where, in the resulting formula $f(x)$, and in the corresponding curve in Figure 1, the variable $x$ attains the discrete quantities $1,2,3 \ldots, 16$ in correspondence to householder age-groups. As shown in Figure 1, the function $f(x)$ in Equation (1) provides a good fit to the 1991 trajectory of age-specific average household size of the Czech Republic. ${ }^{2}$ 
Abraham Akkerman

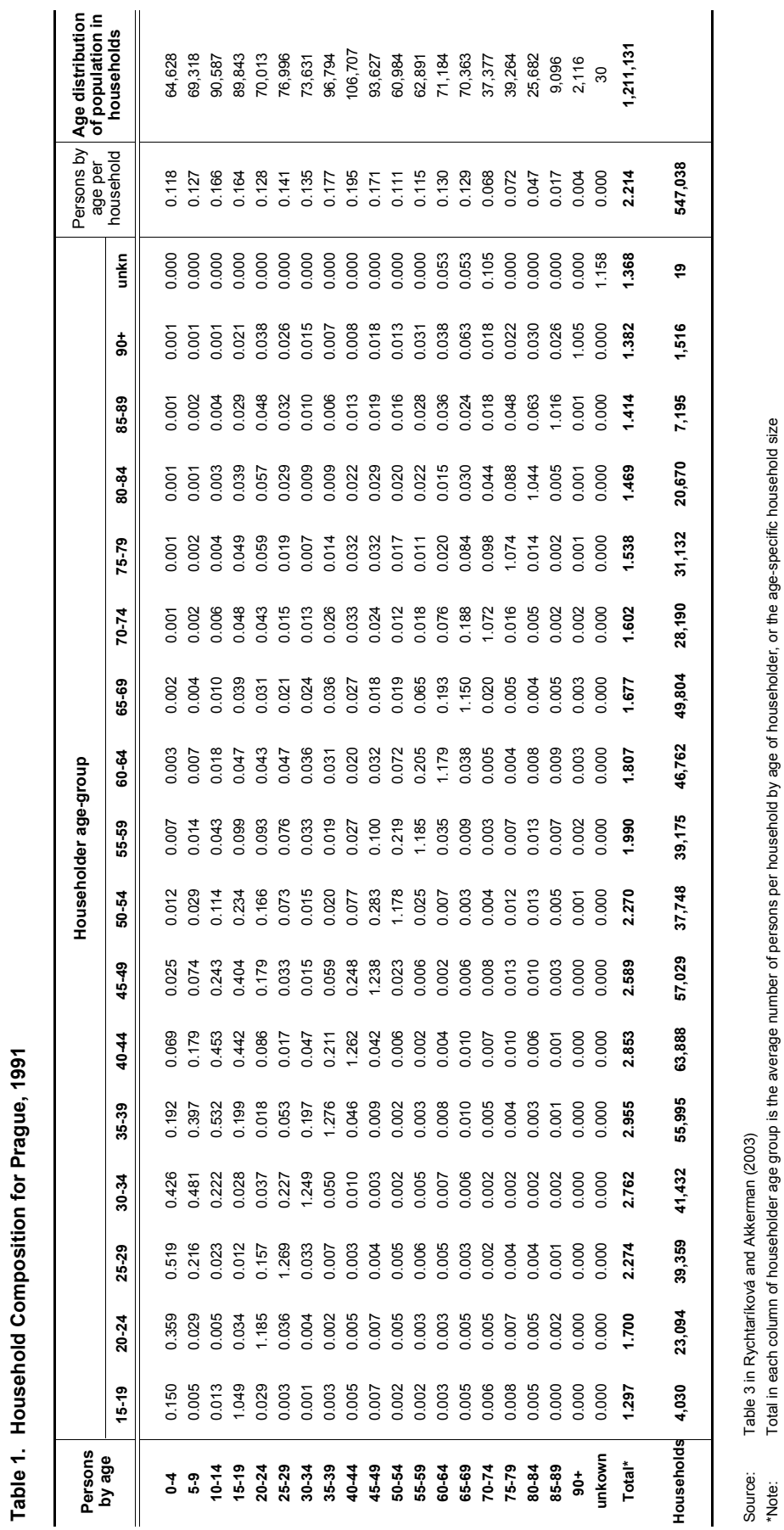


Age-Specific Household Size as a Demographic Aspectc of Regional Disparity: Czech Republic, 1991

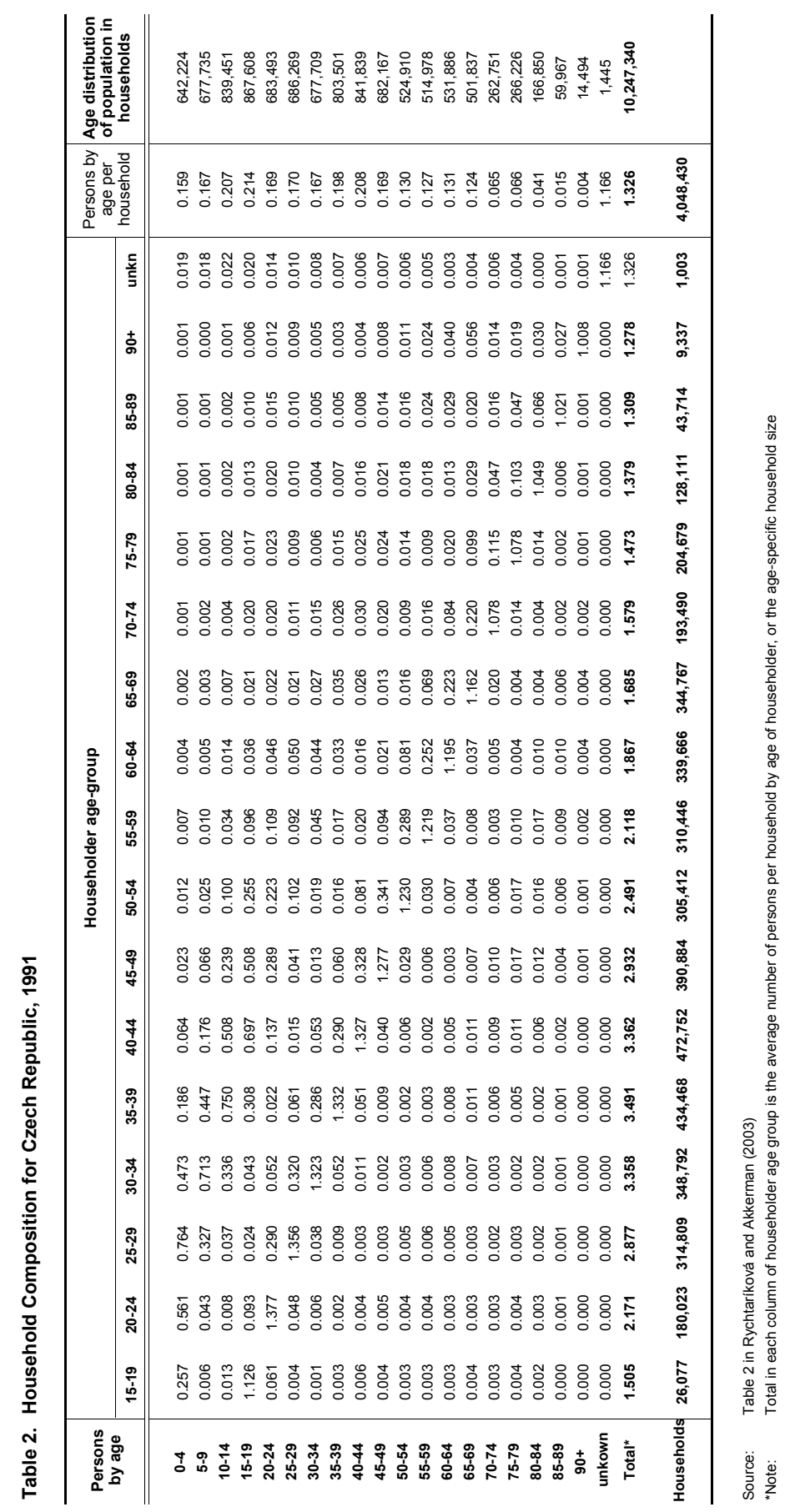


Abraham Akkerman

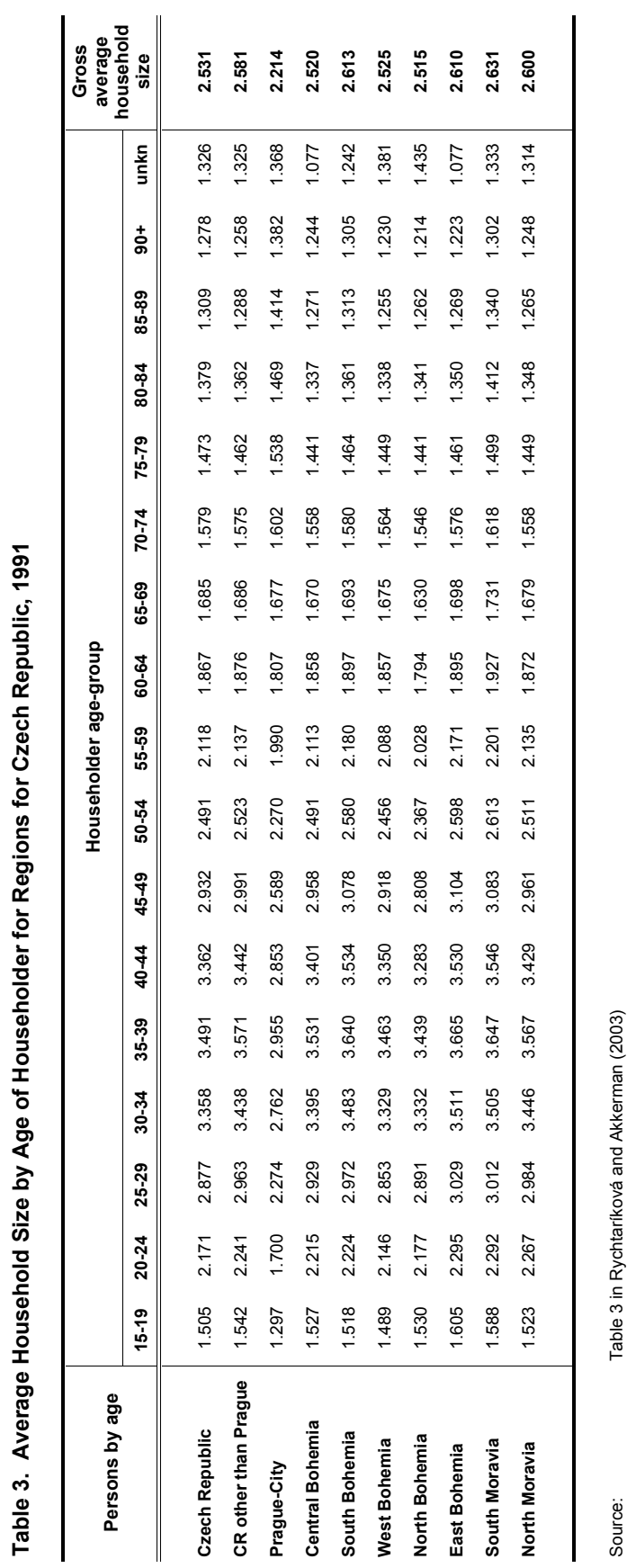


Age-Specific Household Size as a Demographic Aspect

of Regional Disparity: Czech Republic, 1991

The differences in trajectories of age-specific household size between Prague and the rest of the country, show in the following the relation between housing policy and household composition in the Czech Republic.

\section{Regional Trajectories of Age-Specific Household Size in the Czech Republic}

Although sharing similar general features, age-specific household size trajectories within the Czech Republic have also unique differences. Comparison of age-specific values of household size for 1991, in Table 3 and Figure 2, shows a pronounced difference between Prague and the country's remaining seven regional components.

Even though the trajectories for Prague and the other seven regions are similar, there is a striking and consistent contrast. For headship age groups 15-19 to 6569 Prague shows consistently lower values, whereas for age groups 70-74 and older Prague has higher values than the rest of the country. In both Prague and the rest of the country age-specific household size peaks at the headship agegroup 35-39, but this value for Prague (2.96 persons per household) is significantly lower than the corresponding value for the rest of the country ( 3.57 persons per household). The overall (or gross-) average household size for Prague (2.21) is also lower than that for the rest of the country (2.58).

The differences seem to point, initially, to consistency with retirement age. Past evidence would appear to lend some support to the suggestion that changes in housing conditions of households occur following retirement of the householder (Poláková, 2002; Forrest and Leather, 1998). Czech regional differences in postretirement decline of household size, however, deem such a proposition difficult to accept. Careful inspection of Tables 1 and 2 shows that explanation of housing change at retirement age does not clarify the differences in postretirement decline in household size between Prague and the rest of the Czech Republic. Specifically, the sole assumption of housing change at or past retirement does not explain regional differences in post-retirement recruitment of household members.

A much more satisfactory explanation to the incongruity can be sought in the socio-economic difficulties that have shaped the housing market, in Prague in particular, after communism. The dismantling of Czechoslovak socialist housing policy following the Velvet Revolution was precipitated by the misguided belief 


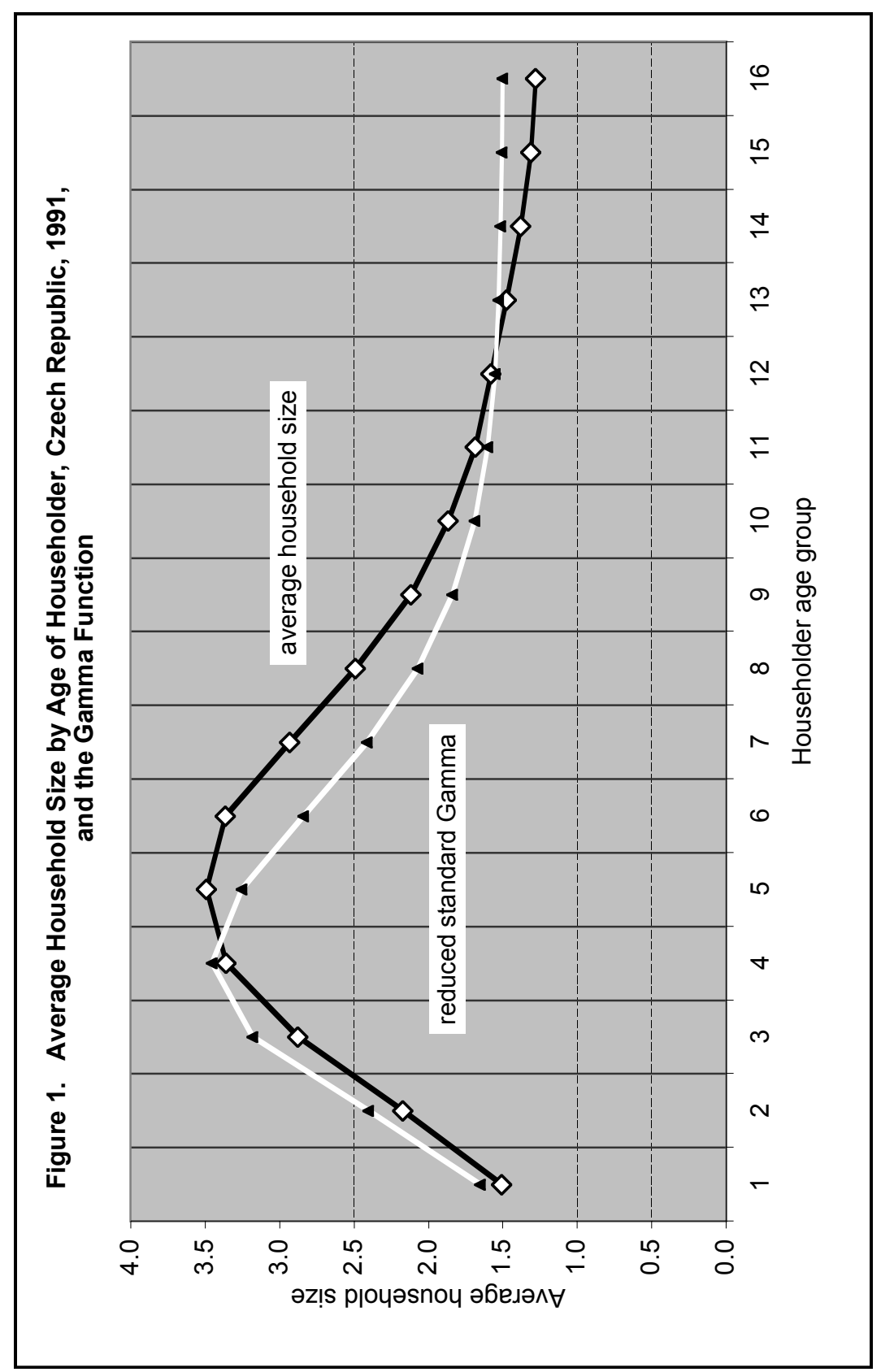


Age-Specific Household Size as a Demographic Aspect of Regional Disparity: Czech Republic, 1991

that the introduction of market economy would create equitable housing conditions. The free market economy following the Velvet Revolution of 1989, however, could not resolve the existing inequities, and the failure of this approach has led to the subsequent adoption of housing mortgage and financing system as a more pragmatic housing policy (Musil, 1995). But for the vast majority of urban residents the combination of wages and the newly introduced financing system has been woefully inadequate, leading to conditions that had inadvertently forced the government to retain some of the socialist housing regulations.

To western observers in the mid-1990s absence of mortgage funds, selective rent controls, and continued public ownership of municipal housing were the impediments to full market formation in the Czech Republic (Reiner and Strong, 1995). Yet the vast gap between affordability of, and need for housing, were for most part, ignored. It was precisely in this regard where government has continued to fulfil an important function in heavily subsidizing rents in government owned housing (Telgarsky et al., 1993). Compared to their counterparts in the west, tenants in government-owned housing throughout Czechoslovakia were paying an extremely small fraction of their incomes for rent.

The rental revenue generated was, accordingly, substantially below the amount needed to cover operating and maintenance expenditures. Enormous government subsidies were provided in the past to make up for the difference. Telgarsky et al. had warned already in 1993 that the economy could ill afford the continuation of housing subsidies at those levels. Indeed, since 1989, it has been recognized that rents would have to be markedly increased if accelerated deterioration of government-owned housing stock, or a major economic crisis, were to be avoided. Recognized, however, was also the fact that while many households may have sufficient incomes to be able to pay more in rent, large rent increases could be deadly for middle- and lower-income groups (Poláková, 2002; Telgarsky et al., 1993).

\section{Household Composition as a Function of Housing Policy and Household Behavior}

The widening gap between Czech housing costs and wages had lead to the continuing retention of state subsidies for government-owned housing. Far in excess to what is known as social housing in countries of the European Union, government-owned rental housing in the Czech Republic plays a central role not only for lower income, but for the entire middle-income range of households. Due to the vastly prohibitive market-cost of housing relative to the average 


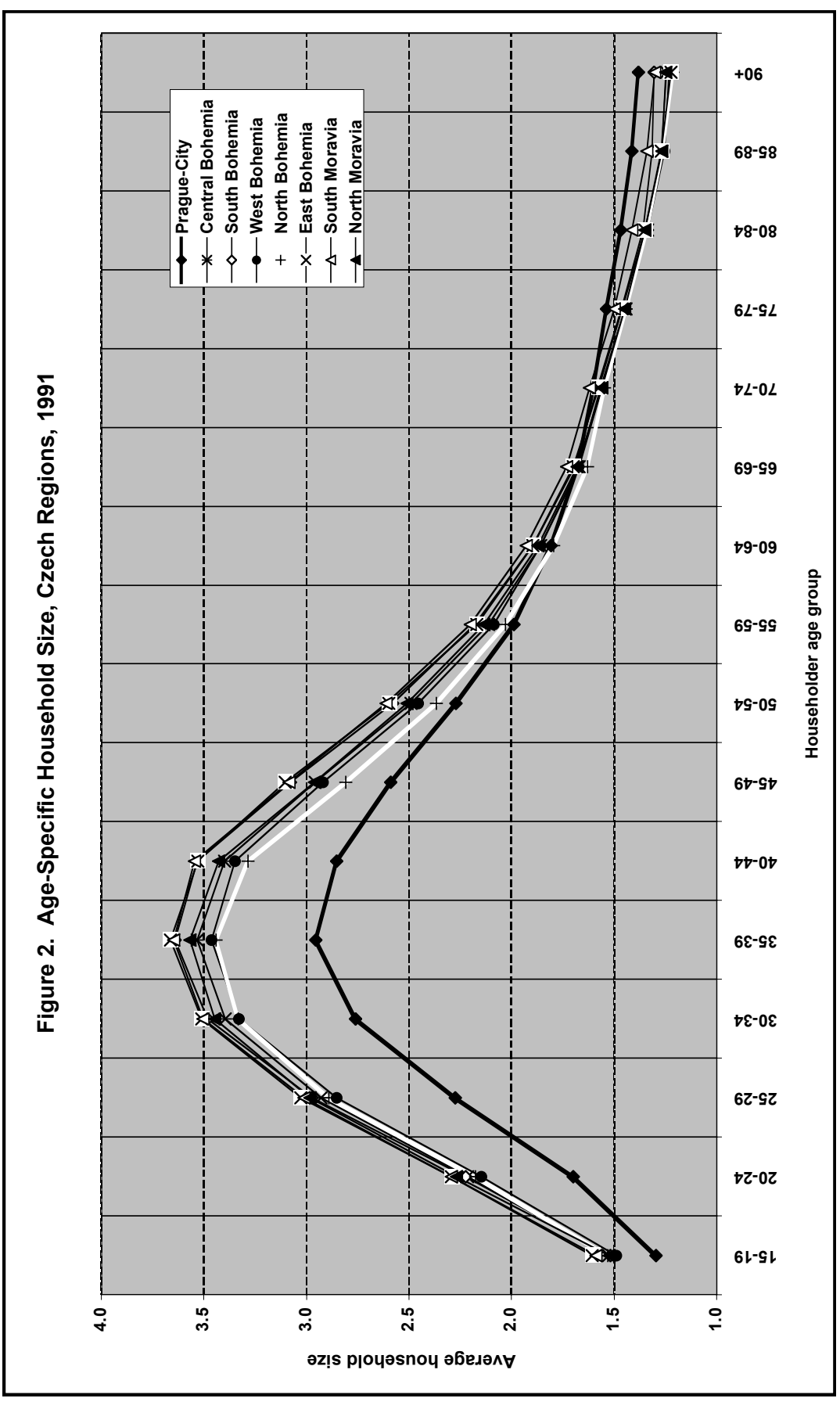


Age-Specific Household Size as a Demographic Aspect of Regional Disparity: Czech Republic, 1991

income, the subsidies could not be simply waved, but rather have continued to be offered as a remnant of the communist era. The conditions emanating from this situation have been outlined by Lux (2000) who detailed how the sector of government-owned housing has been protected from market trends. The differences between market rents in the private rental sector and controlled rents in government-owned housing have been remarkable, sometimes reaching $100 \%$ or more. The largest differentiation between these two housing sectors in the country, not surprisingly, is in Prague.

The rules in effect in 1991, still valid over a decade later, specify that eligible for government-owned rental housing is only a householder registered in a government housing unit, or in case of his or her death, a family member residing in the unit with the householder. The consequences of these rules are not difficult to follow. An aging family member who is registered as the householder in a government-owned rental dwelling recruits a younger family member, often a grandchild, to be registered as a co-resident in the dwelling. Upon death of the householder, the right to continue to reside in the dwelling under the conditions of government-controlled rent transfers to the grandchild. Government-owned dwelling units that eventually become available for sale are offered to the current registered dwellers at heavily reduced cost, virtually without regard to the actual housing market (cf. Lux, 2000).

Since the gap between government-owned housing rents and market rents is the highest in Prague, recruitment of young family members by older householders could be expected to be highest in Prague as well. Such course of behavioral response on the part of households could be expected to have a statistical interpretation in the household composition tables for Prague, and for the rest of the country where the gap is known to be smaller than in Prague. Tables 1 and 2 are, indeed, a clear reflection of this behavior. For entries corresponding to the average number of young, or very young persons who are affiliated with householders past age group 65-69, household composition for Prague (Table 1) shows remarkably higher values than household composition for the entire country (Table 2).

The finding confirms a suggestion by Wolf (1984), in a different context, to the effect that household composition provides a conceptual framework for an explanatory, as well as descriptive, approach to the relationship between government policy and household behavior. While housing policy is determined through an "objective" review by the government in regard to social and economic priorities, household behavior is determined by self-interest and the subjective perception of needs. The relation between these two concepts will require further attention, particularly within the context of housing and the 
Abraham Akkerman

interaction between local communities and the government (cf. also Carmin, 2003)

The recognized benefit of the household composition table, particularly in demographically "smaller" populations such as those of cities or sub-national regions, is the formal linkage between family and household structure, and the aging of the population (Akkerman, 1996). Within the context of the city or the region the need for such methodological linkage becomes crucial with regard to urban development and the planning of residential housing. The joint effect of continuous increase in older age-groups, a relatively rapid decline in very young age-groups, and the growing number of single-parent families along with other changes in family structure, will increasingly call for new methodological tools in the analysis of family structure and housing policy. The notion of household composition seems to address at least some of the newly emerging concerns.

\section{Conclusion}

The tabular representation associated with household composition provides the basis for a conceptual framework in which community demography, reflected in household composition, is linked to housing. The purpose of the present study was to examine the demographic notion of household composition as a gauge of regional disparity within the Czech Republic. The present study propounds the demographic measure of household composition as a quantitative device showing regional disparity within the eight regions comprising the Czech Republic, based on the 1991 census. To the extent that household composition reflects social and economic aspects of housing, the present study suggests that household composition is also a puissant measure of social and economic disparity between regions.

The fortuitous conjuncture of the 1991 census of Czechoslovakia has been that it had occurred halfway between the 1989 collapse of communism in the country, and the 'Velvet Divorce' of 1993. Within the context of regional disparity in the Czech Republic the application of the concept of household composition thus posits a socio-economic aspect of the Soviet demise in Central and Eastern Europe during the latter part of the 20th century. Regional inequalities within former communist countries of Central and Eastern Europe may have been inherited from the past, but their struggle to eliminate them becomes particularly poignant for the ongoing expansion of the EU. During the transition period (1989 and onward), regional inequalities across and within the countries of Central and Eastern Europe have been shown to be greater in economic development than in social wellbeing (Zaniewski, 1992). The observation of Zaniewski had been that changes in social wellbeing during the transition 
Age-Specific Household Size as a Demographic Aspect of Regional Disparity: Czech Republic, 1991

indicate convergence trends in most countries. Pointed out, however, was also the fact that the rate of change in indicators of social wellbeing has been closely associated with pre-existing conditions. The slowest progress in this convergence was reported in economically advanced areas of former communist Europe such as the present day Czech Republic (Zaniewski, 1992).

Household composition, as a yardstick of socio-economic comparison, emerges as a simple yet comprehensive measure aimed at assessment of regional disparities. As an interregional measure household composition emerges not only as a useful demographic parameter, but also as an indicator of social wellbeing. It remains to be seen, however, whether Zaniewski's observation applies to housing and household composition as well. The particular concern for the measurement of regional disparity within the Czech Republic suggests that household measures may carry a significant potential for the appraisal of relative wellbeing between a country's regions. Naturally, future applications of household composition should be carried out for other geographic areas as well.

Changes in living arrangements of households in the 21 st century will undoubtedly impact upon population growth and distribution. A comprehensive conceptual framework for the analysis of both population and households at the level of the region and the city is, therefore, a significant component of a broader socio-economic inquiry and policy. The significance of using the household as a basic population unit is its conceptual link with both population and housing. The link between the demography of households and the economics of housing has had a long tradition of recurrent inquiry (e.g., Cole, 1945: 11-38), and the relationship of household lifecourse with housing needs or housing demand emerges here as a useful new methodological item.

The methodological advantage of the matrix representation of household composition is underscored by the similitude of trajectories of age-specific household size with the reduced standard Gamma probability density function. The suggestion that an analytic function could provide a fit to the trajectory of age specific household size also signals a step towards the formal investigation of the relation between population and housing. The utilization of these findings in regional analysis as well as policy, however, will largely depend on the wider availability of household composition data from censuses or surveys. 
Abraham Akkerman

\section{End Notes:}

1. The Czechoslovak Socialist Republic became a federal state in 1969, by forming the Czech and Slovak Socialist Republics. In 1990 the two geopolitical components of Czechoslovakia were renamed as Czech and Slovak Federative Republics.

2. Even better fit with the 1991 Czech trajectory of age-specific household size is attained by slightly modifying the function

$f(x)$ in Equation (1), so as to yield

$$
h(x)=1.5+5 \mathrm{x}^{\alpha-1} e^{-0.5 \mathrm{x}} / \Gamma(\alpha),
$$

with all parameters remaining identical to those in the original function $f(x)$.

\section{Acknowledgement:}

Part of this study was conducted at the Center for Economic Research and Graduate Education, Prague, Czech Republic. I am indebted to Eva Cermáková, Deputy Director of CERGE, for facilitating this research and for providing me with material resources in the course of this study.

\section{References:}

Akkerman, A. 1994. "Sameness of age cohorts in the mathematics of population growth," British Journal for the Philosophy of Science 45: 679-691.

Akkerman, A. 1996. "A problem in household composition," Mathematical Population Studies 6: 3-18.

Awan, K., J.C. Oding-Smee and C.M.E. Whitehead. 1982. "Household Attributes and the Demand for Private Rental Housing," Economica 49: 183-200.

Balon, E.K. And J. Hol_ík. 1999. “Gabcikovo River Barrage System: The ecological disaster and economic calamity for the inland delta of the Middle Danube," Environmental Biology of the Fishes 54: 1-17. 
Age-Specific Household Size as a Demographic Aspect of Regional Disparity: Czech Republic, 1991

Brzica, D. 2001. "Transformácia a krízovy manazment ako dva prístupy $\mathrm{k}$ reforme podnikovej sféry: Príklad podnikov oceliarskeho priemyslu v Slovenskej republike a v Kórejskej republike v druhej polovici 90. rokov“ ("Transformation and crisis management as two approaches to corporate reform: An example of steel industry companies in the Slovak Republic and the Republic of Korea"), Ekonomick__asopis 49: 539-558.

Burch, T.K. 1970. "Some demographic determinants of average household size: An analytic approach," Demography 7: 61-69.

Carmin, J. 2003. "Local action in a transitional state: Community responses to proposed development in the Czech Republic, 1992-1996," Social Science Quarterly 84: 191-209.

Coale, A.J. and D.R. McNeil. 1972. "The Distribution by age of the frequency of first marriage in a female cohort," Journal of the American Statistical Association 67: 743-749.

Cole, G.D.H. 1945. Building and Planning. London and Toronto: Cassell.

Dedek, O. 1997. The Break-up of Czechoslovakia: An In-depth Economic Analysis. Aldershot and Sydney: Avebury (Ashgate) Publishing.

Drudy, P.J. and M. Punch. 2002. "Housing models and inequality: Perspectives on recent Irish experience," Housing Studies 17: 657-672.

Dustmann, C. 2003. "Return migration, wage differentials, and the optimal migration duration," European Economic Review 47: 353-367.

Ebert, U. 1995. "Income inequality and differences in household size," Mathematical Social Sciences 30: 37-55.

Eskinasi, M. 1995. Changing housing policy and its consequences: The Prague case," Housing Studies 10: 533-548.

Fidrmuc, J. 2000. "Les ajustements aux chocs par les migrations inter-régionales : le cas des Républiques tchèque et slovaque" ("Adjustment to shocks via inter-regional labor mobility: Evidence from the Czech and Slovak Republics"). Revue d'etudes comparatives est-ouest 31(4): 5-26.

Forrest, R. and P. Leather. 1998. "The ageing of the property owning democracy," Ageing and Society 18: 35-63. 
Abraham Akkerman

Frejka, T. 1980. "Fertility trends and policies: Czechoslovakia in the 1970s," Population and Development Review 6: 65-93.

Frejka, T. and G. Calot. 2001. "Cohort reproductive patterns in low-fertility countries," Population and Development Review 27: 103-132.

Garner, T.I. and K. Terrell. 1998. "Household incomes in the Czech and Slovak market economies," Monthly Labor Review 121: 59-62.

Giannias, D.A. 1998. "A quality of life based ranking of Canadian cities. Urban Studies 35: 2241-2251.

Hardman, A. and Y. M. Ioannides. 2004. "Neighbors' income distribution: Economic segregation and mixing in U.S. urban neighborhoods. Journal of Housing Economics 13 (4): 368-382.

Harris, J.R. and M.P. Todaro. 1970. "Migration, unemployment and development: A two sector analysis," American Economic Review 70: 126-142.

Hermanová, E. and T. Kostelecky. 2000. "Regionální diferenciace na trhu bydlení a její príciny" ("Regional differentiation of the housing market and its causes"). Sociologick__asopis 36: 41-56.

Hoem, J.M., D. Madsen, J.L. Nielsen, E.-M. Ohlsen, H.O. Hansen and B. Rennermalm. 1981. "Experiments in modeling recent Danish fertility curves," Demography 18: 231-244.

Hraba, J., A.L. McCutcheon and J. Vecernik. 1999. "Rural and urban differences in economic experiences, anxiety and support for the postcommunist reforms in the Czech and Slovak Republics. Rural Sociology 64: 439-463.

Illner, M. 1998. "The changing quality of life in a post-communist country: The case of Czech Republic,” Social Indicators Research 43: 141-170.

Kancs, A. 2001. Predicting European enlargement impacts: A Framework for general equilibrium. Eastern European Economics 39: 31-63.

Lux, M. 2000. "Sociální nájemné bydlení v CR ve svetle komparativního srovnání" ("Social housing in the Czech Republic in a comparative context”). Sociologicky casopis 36: 157-180. 
Age-Specific Household Size as a Demographic Aspect of Regional Disparity: Czech Republic, 1991

Lux, M. and P. Sunega. 2003. "Modelování rovnovázné úrovne nájemného a dusledky vybranych nástroju bytové politiky" ("Equilibrium rent and housing policy implications"). Finance a úv_r 53: 31-59.

Machonin, P. 1994. "K sociologické komparaci ceské a slovenské spolecnosti" ("Towards a sociological comparison of the Czech and Slovak society"). Sociologia 26: 333 - 345 .

Mapalad-Ruane, M.C.M. and C.B. Rodriguez. 2003. "Measuring urban wellbeing: Race and gender matter," American Journal of Economics and Sociology 62: 461-483.

Marek, D. and M. Baun. 2002. The EU as a regional actor: The case of the Czech Republic," Journal of Common Market Studies 40: 895-919.

Moring, B. 2003. "Nordic family patterns and the North-West European household system," Continuity and Change 18: 77-109.

Musil J. 1995. "The Czech housing system in the middle of transition," Urban Studies 32: 1679-1684.

Pavlínek, P. 1995. "Regional development and the disintegration of Czechoslovakia," Geoforum 26: 351-372.

Pavlínek P. 1992. "Regional transformation in Czechoslovakia: Towards a market-economy," Tijdschrift voor economische en sociale geografie 83: 361-371.

Poláková, O. 2002. Bytová politika (Housing Policy). In V. Sp_vá_ek (ed.), Transformace ceské ekonomiky (Transformation of the Czech Economy). Prague: Linde nakladatelství, pp. 438-447.

Pressat, R. 1978. Statistical Demography, translated and adapted by D.A. Courtney. London: Methuen.

Prucha, V. 1997. Continuity and Discontinuity in the Economic Development of Czechoslovakia, 1918-1991. In A. Teichova (ed.), Central Europe in the Twentieth Century: An Economic History Perspective. Aldershot and Sydney: Ashgate Publishing, pp. 23-41.

Reiner, T.A. and A.L. Strong. 1995. "Formation of land and housing markets in the Czech Republic," Journal of the American Planning Association 61: 200-209. 
Abraham Akkerman

Rychta_íková, J. and A. Akkerman. 2003. "Trajectories of household composition in the demographic profile of the Czech Republic," Population and Environment 24: 225-254.

Synek, M. and T. Kubálek. 1993. "O efektivnosti ceského a slovenského prumyslu" ("On the efficiency of the Czech and Slovak industry"). Politická ekonomie 41: 487-495.

Telgarsky, J.P., G.T. Kingsley, P. Tatian and P. Taj_man. 1993. "Reforma bytové politiky v CSFR" ("Housing policy reform in Czechoslovakia"), Politická ekonomie 41: 21-34.

Uhlí_, D. 1998. "Internationalization, and institutional and regional change: Restructuring post-communist networks in the region of Lanskroun, Czech Republic," Regional Studies 32: 673-685.

Vav_ejnová, M. and I. Moravcíková. 1995. "Household sector in the Czech Republic in transition," Eastern European Economics 33: 76-110.

Wolf, D.A. 1984. "Changes in household size and composition due to financial incentives," Journal of Human Resources 19: 87-103.

Zaniewski, K. 1992. "Regional inequalities in social wellbeing in Central and Eastern Europe," Tijdschrift voor economische en sociale geografie 83: 342-352. 